\title{
Application of Optimum Compaction Energy in the Development of Bricks Made with Construction Trash Soils
}

\author{
T. Lopez-Lara, ${ }^{1}$ C. L. Gonzalez-Vega, ${ }^{1}$ J. B. Hernandez-Zaragoza, ${ }^{1}$ E. Rojas-Gonzalez, \\ D. Carreón-Freyre, ${ }^{2}$ R. Salgado-Delgado, ${ }^{3}$ E. Garcia-Hernandez, ${ }^{3}$ and M. Cerca ${ }^{2}$ \\ ${ }^{1}$ División de Estudios de Posgrado, Facultad de Ingeniería, Universidad Autónoma de Querétaro, Cerro de las Campanas S/N, \\ Colonia Las Campanas, 76010 Querétaro, QRO, Mexico \\ ${ }^{2}$ Laboratorio de Mecánica Multiescalar de Geosistemas, Centro de Geociencias, Universidad Nacional Autónoma de México, \\ Boulevard Juriquilla 3001, Colonia Juriquilla, 76230 Querétaro, QRO, Mexico \\ ${ }^{3}$ División de Estudios de Posgrado e Investigación, Departamento de Ingeniería, Química y Bioquímica, \\ Instituto Tecnológico de Zacatepec, Calzada Tecnológico 27, 62780 Zacatepec, MOR, Mexico \\ Correspondence should be addressed to T. Lopez-Lara; lolte@uaq.mx
}

Received 8 February 2014; Accepted 17 April 2014; Published 8 May 2014

Academic Editor: Gonzalo Martínez-Barrera

Copyright (C) 2014 T. Lopez-Lara et al. This is an open access article distributed under the Creative Commons Attribution License, which permits unrestricted use, distribution, and reproduction in any medium, provided the original work is properly cited.

In general, bricks frequently show different densities and therefore different resistances because the compaction energy is not considered in their production. Expansive soils represent a problem for light buildings over them because of volumetric instability. A generalized solution has been to extract them and substitute them by inert soil; thus they become construction trash. So, in this work the compaction energy aspect and the use of construction trash soils in the elaboration of resistant masonry bricks of homogeneous and controlled density are a new contribution in the production of bricks of better quality. First, the soil was stabilized with $\mathrm{CaOH}$ which leads to a decrease in its volumetric changes. Then, they were compacted with a specific energy for obtaining an optimal and maximum controlled density to ensure an increase in strength. Our results show that two optimal compaction energies can be considered with respect to the variation of optimum moisture in masonry bricks of expansive soil stabilized with lime. The first is when the optimal humidity reaches its smallest value (integrated soil lumps) and the second is when humidity increases (disintegrated soil lumps), after reaching its lowest value. We also conclude that high compaction energy does not improve density values.

\section{Introduction}

Many countries in the world have to deal with the problem of expansive clays (vertisols) such as Mexico, the USA, Australia, South Africa, India, and Israel among others. In particular several regions of Mexico, for instance, in the lacustrine planes located at the states of Querétaro, Guanajuato, Michoacán, Tamaulipas, Morelos, Sonora, Baja California, Veracruz, Chiapas, and Campeche, deposits of this type of soils can be found. The constant growing of human settlements has provoked the urban stain to be extended up to agricultural lands, thus forcing to build on top of them. These soils are mainly of the expansive type and show volumetric instability due to humidity variations. Because of their expansion they bring out fissures in light constructions above them [1]. Due to this problem, these soils are replaced by soils with inert features [2], thus remaining as trash soils. The objective of this study is to use this trash expansive soil via a composite material, soil- $\mathrm{CaOH}$, to produce bricks of optimal and controlled compaction energy for masonry, which is neglected in the production of this kind of bricks.

To achieve this, the trash expansive soil was stabilized with $\mathrm{CaOH}$ to eliminate its volumetric changes and then it was compacted at different energies per volume (cubic meter) for controlling different densities and to obtain an optimal-controlled density and optimum moisture to assure a larger strength in the material. Then, test specimens with these densities were made and subjected to unconfined compressive tests. The compaction energy was selected to be the best reasonable strength. Thereafter, masonry bricks were subjected to tests of stress rupture and strength to first fissure. 
In general, bricks frequently show different densities and therefore different resistances because the compaction energy is neglected in the production of this kind of bricks. So, the compaction energy aspect in this work is a new contribution in the production of bricks of better quality.

Therefore, after determining the ideal specific compaction energy of a lime-treated expansive soil, we will be able to use the resulting values of maximum density and optimum moisture, which can be applied with some bricks compressor. With this procedure, sustainable bricks of high and homogeneous resistance can be obtained.

\section{Background}

The applications of the use of soils treated with $\mathrm{CaOH}$ are, for example, in the construction of bed-layers of pavements, in the stabilization of dams made of earth, and as a layer for supporting shallow foundations [3]. This technique is conventional for improving expansive soils properties [4]. This is so, because the $\mathrm{CaOH}$ helps stop the expansion of these types of soils [5]. Earth is a cheap, ecological, and plenty material for construction. Indeed, it has been used widely in walls construction around the world, especially in developing countries [6]. About 30\% of the world population lives in buildings made of earth. Near $50 \%$ of the population of developed countries, including most of the rural population, and at least $20 \%$ of urban and marginal population live in buildings where earth was used for its construction [7].

Manufacture of ceramic pieces for masonry represents a very important economical activity in some towns of Mexico and other developing countries. These pieces are preferred because of their cultural reasons, accessibility, and long history. Indeed they have been used since 4000 years ago in Egypt and they represent the first materials manufactured for buildings [8]. However, the low quality control of manufacturing of these pieces leads to strength variations, dimensions, and density. Moreover, because of its production environmental problems emerge such as a highenergy consumption as well as high emissions of carbon dioxide [9], thus causing damage to the public health [10]. This is so because wood, recycled automobile oil, coke, heavy oil, used tires, garbage, and plastics [11] are used as fuels for its production.

The study of different materials for the fabrication of pieces to substitute bricks of burned clay has been the aim of many researchers worried about the environment, the use of natural resources, and the recycling of industrial trashes. Red clay is a trash subproduct from the aluminum extraction. In this respect, there have been efforts for producing these bricks with fly ashes and a small percentage of $\mathrm{CaOH}$. These pieces were tested by accelerated abrasion and considered ideal for its use as low-cost material for shelters [12].

Bricks made of fly ashes, $\mathrm{CaOH}$, and calcium sulfide are one of the best alternatives for bricks of conventional burned clay. Comparative results indicate that the former are lighter in weight, last in aggressive environments, and have enough strength to be used in the construction of buildings [13].

Compressive strength increases 2.5 times when the percentage of cement is doubled from 6 to $12 \%$ in compressed earth-cement blocks with very sandy soils. The rate of humidity absorption depends greatly on cement content. Pores size diminishes with the increase of cement content in the block [14].

Since fifty years ago, the introduction of blocks made of compressed earth was seen as an important step. These blocks are made via compression of a humid mixture of earth (9095\%) and cement (5-10\%), thus forming strong and dense blocks used for walls. While their properties are well known with respect to their characteristics of initial performance, there has been little research about their durability in the long term and the deterioration due to long exposition of environmental factors [15].

Achenza and Fenu [16] reported bricks with adobe stabilized with vegetal fibers and a composite of natural polymers. It seems that the latter modified the porosity and apparent density of the bricks and improved their behavior under water action and their compressive strength too.

Soil compaction produces an increase in resistance and decreased deformability. This process is obtained with suitable techniques applied on the soil, which improves the dry specific weight decreasing its empty spaces. Therefore, there are two main factors that determine the best density of soil material: moisture and the specific energy applied.

The specific energy of soil compaction is the compaction effort applied to the soil per unit volume and is determined using the weight, height of drop, and number of blows of a hammer to compact a volume of soil placed in layers into a mold. Therefore, Proctor found a moisture entitled "optimum" that produces the maximum dry weight under a given specific compaction energy [17].

\section{Tests and Experimental Methods}

3.1. Geotechnical Characterization. Geotechnical characterization of the expansive soil under study was made such as gradation test, according to ASTM D 422 standard [18]. This was done to know the grain size distribution and the proportion of sizes of its constitutive particles. Then, following the ASTM 4318 standard [19], the liquid and plastic limits were determined, as well as the shrinkage limit [20]. With this information, the soil was classified by the Unified Soil Classification System (USCS) [21]. Its specific weight and specific gravity were obtained following the ASTM D 854 standard [22].

3.2. Stabilization of Soil with $\mathrm{CaOH}$. For stabilization of expansive clay, three different doses of $\mathrm{CaOH}$, namely, 6, 8, and 10 percent of its dry weight, were aggregated to each sample. For each dose, the plasticity limits were obtained. The aim was to find the optimal $\mathrm{CaOH}$ quantity for abating volumetric changes.

3.3. Application of Compaction Energies. The compacting procedure for the stabilized soil was compaction by layers with a weight falling from a controlled height (Proctor compaction procedure). The compaction energies per cubic meter were Proctor standard $(600 \mathrm{kN}-\mathrm{m})$ and modified 
Proctor (2700 kN-m), following the procedures ASTM D 698 [23] and D 1557 [24], respectively. Then, higher compaction energy $(4000 \mathrm{kN}-\mathrm{m})$ was applied. Results of these tests were the determination of the maximum dried density and the optimum moisture. This procedure is supposed to increase soil density. It should be pointed out that the modified soils tests specimens had the optimal amount of $\mathrm{CaOH}$, previously determined.

3.4. Unconfined Compressive Strength. Test specimens of modified soils were subjected to unconfined compression [25] at different ages ( $7,14,30$, and 60 days) and the compaction energies mentioned above. This was done to define the best behavior and strength.

3.5. Fabrication of the Brick Ceramic Material. Once the dose and compaction energy were settled, bricks of $19 \mathrm{~cm}$ long, $10 \mathrm{~cm}$ width, and $5 \mathrm{~cm}$ height were made. Then, they were subjected to tests for determining the break modulus and the strength to first fissure [26] for comparison with commercial bricks.

\section{Results}

4.1. Geotechnical Properties of Soil. By gradation analysis, via dry and humid, it was determined that the soil was a material with fines, since $94.8 \%$ of its particles went through a sieve $200(0.074 \mathrm{~mm})$. The liquid limit was $70.21 \%$ and the plastic limit was $27.56 \%$; thus the plastic index was $42.64 \%$. From these results, the soil can be classified as high compressibility clay $(\mathrm{CH})$ according to the Unified Soil Classification System (USCS), [21]. The volumetric shrinkage limit was $8.68 \%$, specific weight of $15.68 \mathrm{kN} / \mathrm{m}^{3}$, and specific gravity of soil as 2.52 . From the gradation via humid analysis, the percentage of particles less than $0.002 \mathrm{~mm}$ was $19.5 \%$. With this data and the plasticity index, the activity index of the clay was determined as 4.5 . Using the activity criteria the soil has a highly expansive potential [2].

4.2. Soil Stabilized with $\mathrm{CaOH}$. Several test specimens of soil added with $\mathrm{CaOH}$ with different percentages in dry weight were prepared. Plasticity limits versus percentages of $\mathrm{CaOH}$ are shown in Figure 1. In this figure it can be observed that the plasticity limits properties are stabilized starting with $8 \%$ $\mathrm{CaOH}$. Indeed, at that percentage there is little or nil variation of the liquid limit and the plastic index, even increasing the $\mathrm{CaOH}$ content. The natural soil corresponds to the $0 \%$ of $\mathrm{CaOH}$. Moreover, the soil classification changes from $\mathrm{CH}$ (high compressibility clay) to ML (lime of low plasticity); thus, it has properties of a low plasticity soil, that is, little or nil volumetric change.

4.3. Application of Compaction Energies. The optimum quantity of $\mathrm{CaOH}$ placed in the soil composite was determined by its plasticity properties and was $8 \%$ (Figure 1 ). To include a broad range of energies, first this study includes two energies from two common assays of soils compaction, $600(\mathrm{kN}-$ $\mathrm{m}) / \mathrm{m}^{3}$ at Proctor standard and $2700(\mathrm{kN}-\mathrm{m}) / \mathrm{m}^{3}$ at Proctor

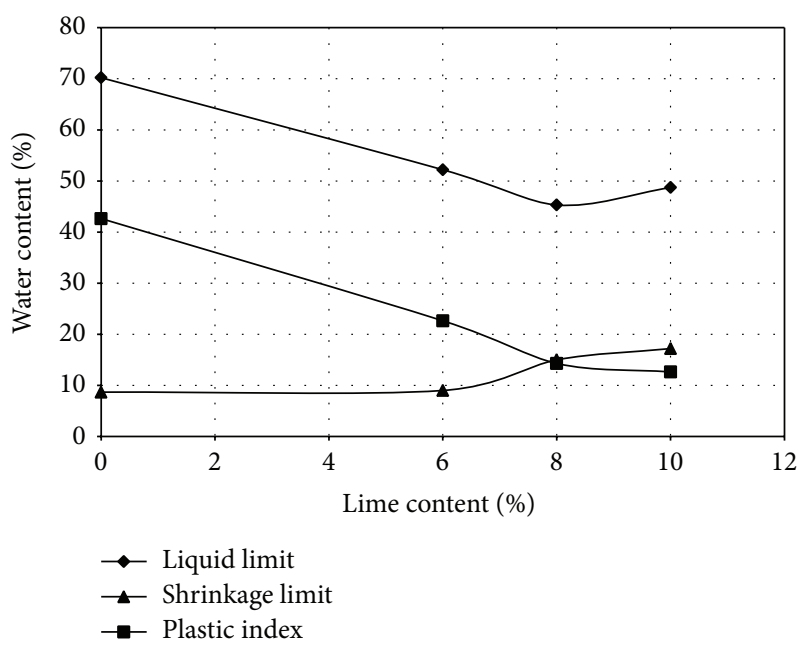

FIgURE 1: Atterberg limits versus lime content.

modified, and proposes a third higher energy value of 4000 $(\mathrm{kN}-\mathrm{m}) / \mathrm{m}^{3}$. After applying these three energies, we observe that the best dried density of the material corresponded to the Proctor standard energy. Then with the objective of identifying the nearest energy value, the following tests were performed between values of Proctor standard and Proctor modified energies. These were 1500, 1800, 2100, and 2400 $(\mathrm{kN}-\mathrm{m}) / \mathrm{m}^{3}$. Values for maximum dry density and optimum moisture content for the above conditions are shown in Table 1.

When the energy compaction of the soil increases from 600 to $2100(\mathrm{kN}-\mathrm{m}) / \mathrm{m}^{3}$, the density increases and the optimum moisture content decreases due to compression of the soil (Table 1). Then, the next increment of the compaction energy $\left(2400(\mathrm{kN}-\mathrm{m}) / \mathrm{m}^{3}\right)$ causes an increase in density and a sudden increase in moisture, which is likely due to dispersion of lumps of the soil which generates more smaller soil grains and therefore more contact areas surrounded by water which helps accommodate the soil. This energy causes a small final increase in its density. After $2400(\mathrm{kN}-\mathrm{m}) / \mathrm{m}^{3}$, the density tends to decrease probably due to increasing dispersion of soil aggregates into discrete units by mechanical means (increasing application of energy) [17]. Therefore additional soil dispersions generate increase of water content. This caused a poor compaction of the material (low density values) because water cannot move instantaneously under the compacting hammer blows [17].

Therefore two optimal compaction energies can be considered with respect to the variation of optimum moisture, the first when the optimal humidity reaches its smallest value and the second when it increases, after reaching its lowest value.

4.4. Strength to Unconfined Compression. Stabilized-soils tests specimens were prepared and subjected to unconfined compression, following the ASTM D 2166 standard [25]. Tests specimens were subjected to specific compaction energies of 600 (Proctor standard), 1500, 1800, 2100, 2400, 2700 
TABLE 1: Compaction properties and unconfined compressive strength at different ages.

\begin{tabular}{|c|c|c|c|c|c|c|}
\hline \multicolumn{3}{|c|}{ Compaction data } & \multicolumn{4}{|c|}{ Unconfined compressive strength (MPa) } \\
\hline $\begin{array}{l}\text { Energy/m } \mathrm{m}^{3} \\
(\mathrm{kN}-\mathrm{m}) / \mathrm{m}^{3}\end{array}$ & $\begin{array}{l}\text { Optimum } \\
\text { moisture } \\
\text { content }(\%)\end{array}$ & $\begin{array}{c}\text { Maximum dry } \\
\text { density } \\
\left(\mathrm{kN} / \mathrm{m}^{3}\right)\end{array}$ & 7 days & 14 days & 30 days & 60 days \\
\hline 600 & 35.00 & 12.74 & 0.78 & 0.97 & 1.06 & 1.41 \\
\hline 1500 & 33.30 & 14.70 & 1.32 & 2.01 & 2.71 & 3.57 \\
\hline 1800 & 31.53 & 15.09 & 1.44 & 2.29 & 3.06 & 4.08 \\
\hline 2100 & 31.40 & 15.29 & 1.42 & 2.35 & 3.20 & 4.25 \\
\hline 2400 & 34.20 & 15.39 & 1.63 & 2.62 & 3.57 & 4.74 \\
\hline 2700 & 38.20 & 12.25 & 0.49 & 0.40 & 0.42 & 0.50 \\
\hline 4000 & 37.82 & 12.25 & 0.45 & 0.37 & 0.40 & 0.48 \\
\hline
\end{tabular}

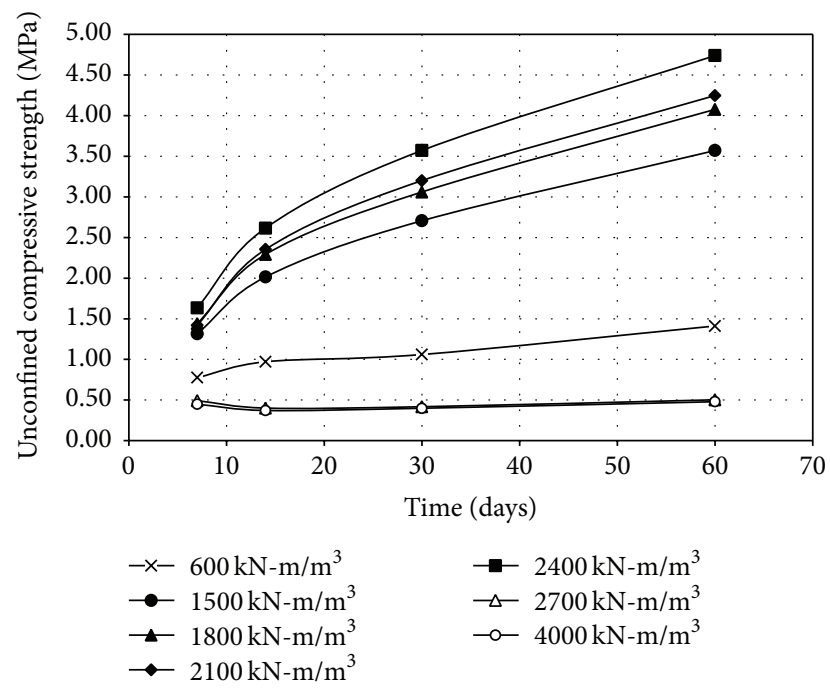

Figure 2: Composite strength for different specific compaction energies and ages.

(Proctor modified), and $4000(\mathrm{kN}-\mathrm{m}) / \mathrm{m}^{3}$. Results are plotted in Figure 2. Figure 2 shows that the increase in density causes increases in resistance.

From Figure 2, the best strengths were obtained with the two optimal compaction energies considered (2100 and $\left.2400(\mathrm{kN}-\mathrm{m}) / \mathrm{m}^{3}\right)$, the first when the optimal humidity reaches its smallest value and the second when it increases, respectively, after reaching its lowest value. This work applied the compaction effort value when the optimal humidity reaches its smallest value, $2100(\mathrm{kN}-\mathrm{m}) / \mathrm{m}^{3}$, to obtain the best dry density of the clay composite with $8 \%$ of $\mathrm{CaOH}$; this is because it is more accurate to find the smallest value of moisture in similar experiments.

4.5. Rupture Stress and Fracture Stress of the Brick Ceramic Material. To determine these values, test specimens were prepared with dimensions: $19 \mathrm{~cm}$ long, $10 \mathrm{~cm}$ width, and $5 \mathrm{~cm}$ height, with ages of 7, 14, 30, and 60 days, and tested according to the ASTM C67 standard [26]. Results are displayed in Table 2 .
TABLE 2: Rupture stress and fracture stress of the proposed brick and some commercial products.

\begin{tabular}{lcc}
\hline Material & $\begin{array}{c}\text { Rupture stress } \\
(\mathrm{MPa})\end{array}$ & $\begin{array}{c}\text { Fracture stress } \\
(\mathrm{MPa})\end{array}$ \\
\hline Proposed brick (7 days) & 0.09 & 1.56 \\
Proposed brick (14 days) & 0.16 & 2.51 \\
Proposed brick (30 days) & 0.31 & 3.33 \\
Proposed brick (60 days) & 0.37 & 3.81 \\
Burned clay brick & 0.45 & 3.08 \\
Block (cement) & 0.20 & 5.91 \\
"Sillar" & 0.01 & 2.38 \\
Adobe & 0.16 & 1.32 \\
\hline
\end{tabular}

From Table 2, it can be observed that the best results for the proposed brick under study were obtained at 60 days. These were compared with commercial pieces for masonry, tested under the same norm. Moreover, it can be said that the proposed brick overcame the strength of burned clay brick, "sillar," and adobe, close to the maximum fracture stress corresponding to the brick. The "sillar" is a regional brick for construction. This is a cut material extracted from sedimentary rocks as shale.

\section{Conclusions}

With trash expansive clay, a brick with $\mathrm{CaOH}$ with optimalcontrolled density could be obtained. The amount of $\mathrm{CaOH}$ to avoid volumetric changes on this type of soils was $8 \%$.

We conclude that in expansive soils treated with lime two optimal compaction energies can be considered with respect to the variation of a determined optimum moisture: the first when the optimal humidity reaches its smallest value and the second when it increases, after reaching its lowest value. This probably occurs due to the continuous increase in compaction energy that causes the soil particles and humidity to achieve their best accommodation: first with intact soil particles (lumps) and then with disintegrated particles of soil, respectively. Higher compaction energy values do not improve density. The increase in density causes increases in resistance. This work applied the compaction effort value 
when the optimal humidity reaches its smallest value to obtain the best dry density.

The proposed sustainable brick made of construction trash soil has a maximum controlled density and better mechanical behavior when compared to another commercial masonry pieces around the region (burned clay brick, "sillar," and adobe). In addition the mechanical properties of the composite increase with time.

\section{Conflict of Interests}

The authors declare that there is no conflict of interests regarding the publication of this paper.

\section{References}

[1] A. Seco, F. Ramírez, L. Miqueleiz, and B. García, "Stabilization of expansive soils for use in construction," Applied Clay Science, vol. 51, no. 3, pp. 348-352, 2011.

[2] F. H. Chen, Foundations on Expansive Soils, Elsevier Scientific, Amsterdam, The Netherlands, 1988.

[3] N. C. Consoli, L. da Silva Lopes, and K. S. Heineck, "Key parameters for the strength control of lime stabilized soils," Journal of Materials in Civil Engineering, vol. 21, no. 5, pp. 210216, 2009.

[4] J.-L. Zheng, R. Zhang, and H.-P. Yang, "Highway subgrade construction in expansive soil areas," Journal of Materials in Civil Engineering, vol. 21, no. 4, pp. 154-162, 2009.

[5] R. L. Buhler and A. B. Cerato, "Stabilization of Oklahoma expansive soils using lime and Class C Fly ash," in Problematic Soils and Rocks and In Situ Characterizatio, vol. 162 of ASCE Geotechnical Special Publication, pp. 1-10, Denver, Colo, USA, February 2007.

[6] S. Sheweka, "Using mud bricks as a temporary solution for Gaza reconstruction," Energy Procedia, vol. 6, pp. 236-240, 2011.

[7] D. Silveira, H. Varum, A. Costa, T. Martins, H. Pereira, and J. Almeida, "Mechanical properties of adobe bricks in ancient constructions," Construction and Building Materials, vol. 28, no. 1, pp. 36-44, 2012.

[8] A. Lyons, Ceramic Materials for Architects and Builders, Butterworth-Heinemann, Oxford, UK, 3rd edition, 2006.

[9] A. S. Muntohar, "Engineering characteristics of the compressed-stabilized earth brick," Construction and Building Materials, vol. 25, no. 11, pp. 4215-4220, 2011.

[10] C. W. Bruce, A. Y. Corral, and A. S. Lara, "Development of cleaner-burning brick kilns in Ciudad Juarez, Chihuahua, Mexico," Journal of the Air \& Waste Management Association, vol. 57, no. 4, pp. 444-456, 2007.

[11] A. Y. Corral Avitia, A. de la Mora Covarrubias, A. D. Cota Espericueta, R. Corral Díaz, K. A. Carrasco Urrutia, and L. E. Santana Contreras, "The risk mapping as an instrument technician for the relocation of the brick industry of the municipality of Juarez, Mexico," Revista Internacional de Contaminacion Ambiental, vol. 26, no. 1, pp. 17-26, 2010.

[12] A. Dass and S. K. Malhotra, "Lime-stabilized red mud bricks," Materials and Structures, vol. 23, no. 4, pp. 252-255, 1990.

[13] S. Kumar, "Fly ash-lime-phosphogypsum cementitious binder: a new trend in bricks," Materials and Structures, vol. 33, no. 225, pp. 59-64, 2000.
[14] B. V. V. Reddy and K. Gourav, "Strength of lime-fly ash compacts using different curing techniques and gypsum additive," Materials and Structures, vol. 44, no. 10, pp. 1793-1808, 2011.

[15] A. G. Kerali, "In-service deterioration of compressed earth blocks," Geotechnical \& Geological Engineering, vol. 23, no. 4, pp. 461-468, 2005.

[16] M. Achenza and L. Fenu, "On earth stabilization with natural polymers for earth masonry construction," Materials and Structures, vol. 39, no. 285, pp. 21-27, 2006.

[17] M. D. Braja, Principles of Geotechnical Engineering, Cengage Learning, United States of America, 7th edition, 2010.

[18] "Standard Test Method for Particle-Size Analysis of Soils," ASTM D422-63, Annual Book of ASTM Standards, 2007.

[19] "Standard Test Methods for Liquid Limit, Plastic Limit and Plasticity Index of soils," ASTM D4318-10, Annual Book of ASTM Standards, 2010.

[20] "Standard Test Method for Shrinkage Factors of Soils by the Mercury Method (Withdrawn 2008)," ASTM D 2427-04, Annual Book of ASTM Standards, 2008.

[21] "Standard Test Method for Classification of Soils for Engineering Purposes," ASTM D 2487-93, Annual Book of ASTM Standards, 1993.

[22] "Standard Test Methods for Specific Gravity of Soil Solids by Water Pycnometer," ASTM D 2854-10, Annual Book of ASTM Standards, 2010.

[23] "Standard Test Methods for Laboratory Compaction Characteristics of Soil Using Standard Effort (12400ft-lbf/ $\mathrm{ft}^{3}(600 \mathrm{kN}$ $\left.\mathrm{m} / \mathrm{m}^{3}\right)$ ), ASTM D698-00a, Annual Book of ASTM Standards, 2000.

[24] "Standard Test Methods for Laboratory Compaction Characteristics of Soil Using Modified Effort $\left(56000 \mathrm{ft}-\mathrm{lbf} / \mathrm{ft}^{3}(2700 \mathrm{kN}\right.$ $\left.\mathrm{m} / \mathrm{m}^{3}\right)$ ), ASTM D1557-12, Annual Book of ASTM Standards, 2012.

[25] "Standard Test Method for Unconfined Compressive Strength of Cohesive Soil," ASTM D2166-00, Annual Book of ASTM Standards, 2000.

[26] "Standard Test Methods for Sampling and Testing Brick and Structural Clay Tile," ASTM C67-13a, Annual Book of ASTM Standards, 2013. 

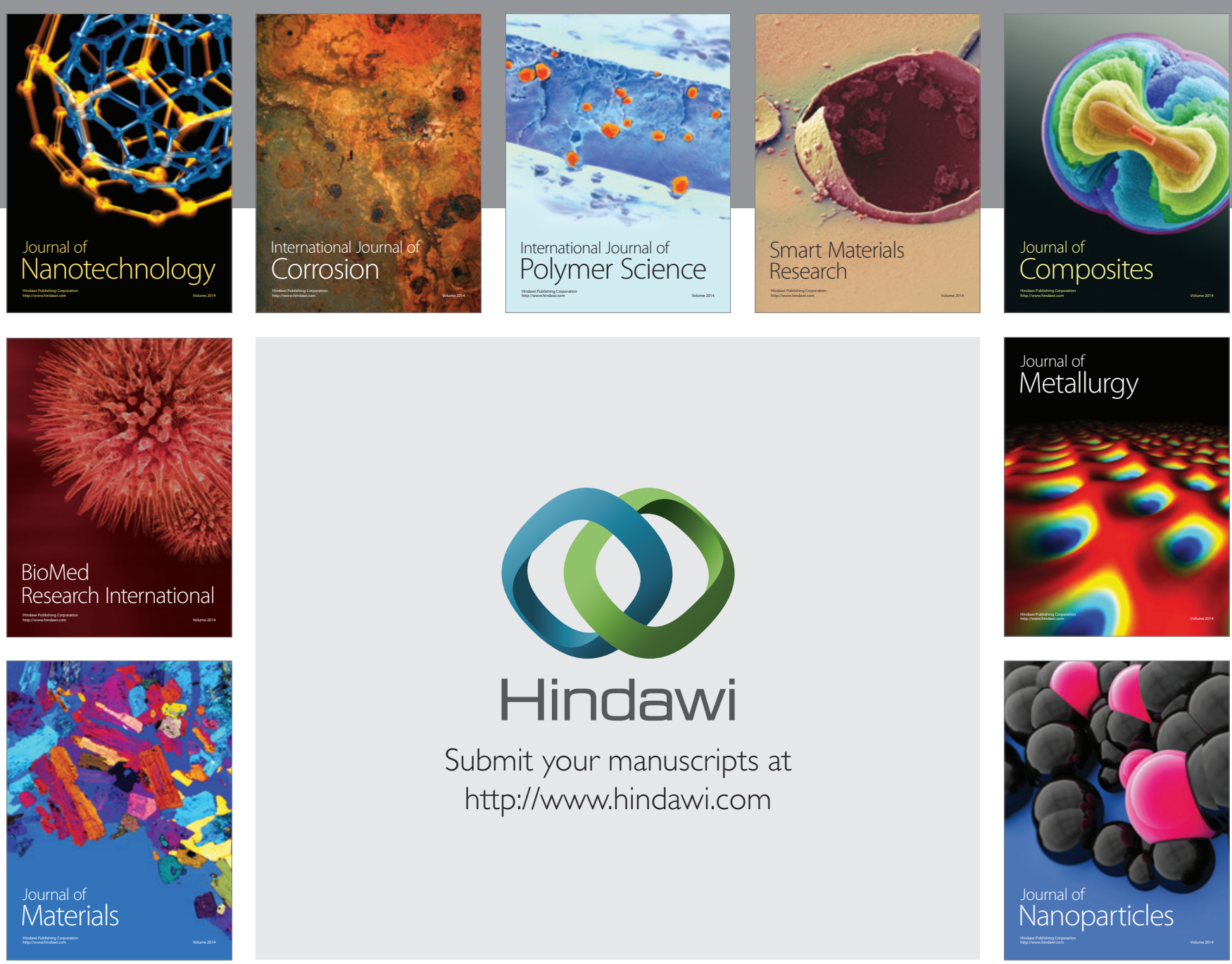

Submit your manuscripts at http://www.hindawi.com
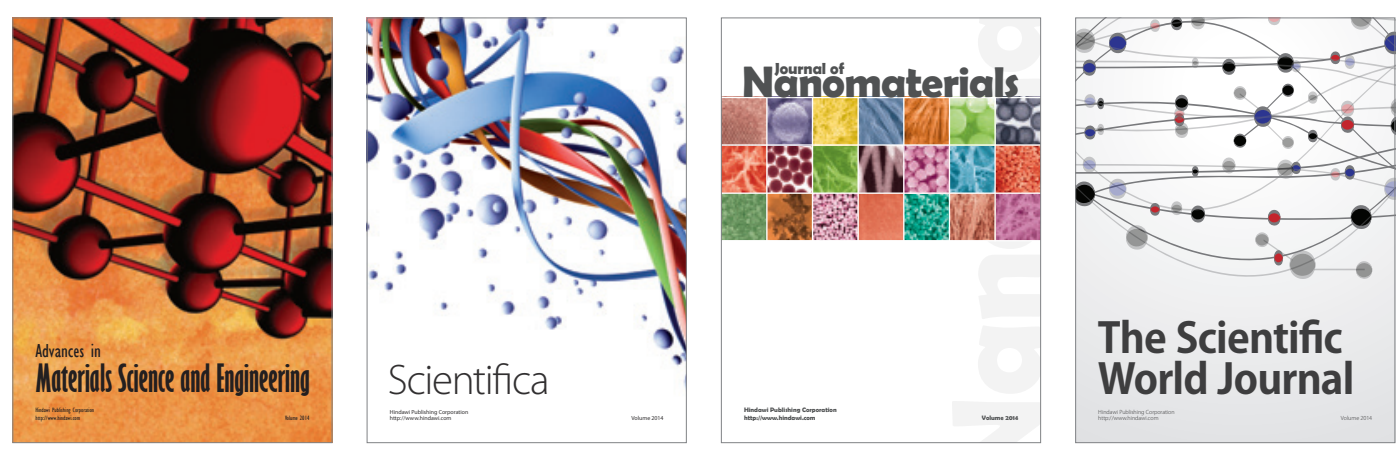

\section{The Scientific World Journal}
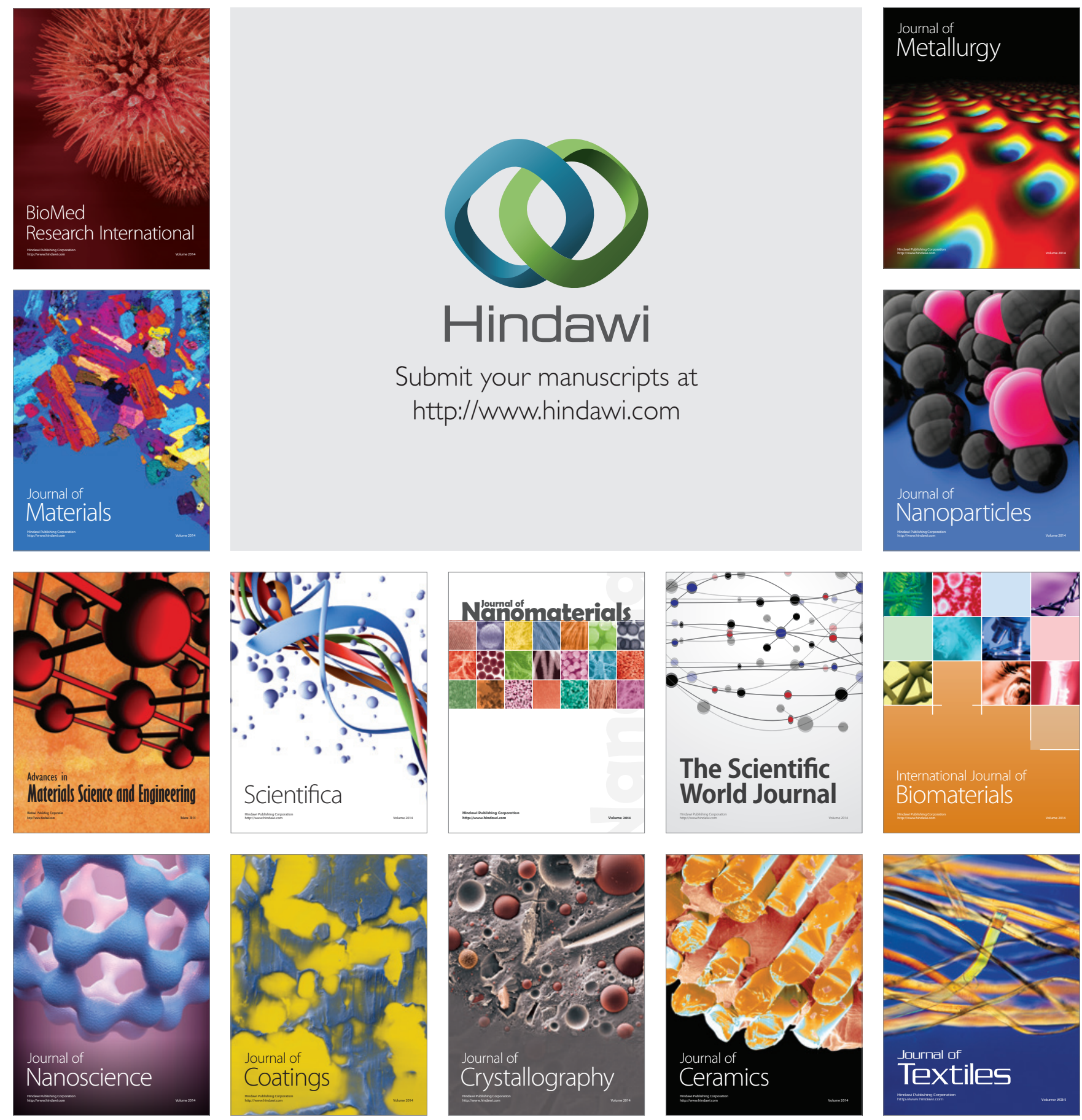